\title{
Post Harvest Loss Management and Quality Control of Fruits and Vegetables in Ethiopia for Securing Food and nutrition - A review
}

\author{
Melkamu Workineh ${ }^{1 *} \quad$ Hewan Lemma $^{2}$ \\ 1.Debre markos university, College of agriculture and Natural Resource, department of \\ Horticulture (Horticulture). P.O.BOX. 269, Ethiopia \\ 2.Debre Markos University, Burie Campus, department of Horticulture (Horticulture). P.O.BOX. 168, Ethiopia
}

\begin{abstract}
High quality and disease free produce with a good shelf life is the result of sound production practices providing food and nutrition security for the community. Therefore, this review will be focused on the postharvest management include harvesting, handling, packaging, storage, transportation, role of mass media, policy makers, marketing, hygiene and sanitation, ultimate utilization of fruits and vegetables to enhance food and nutrition security. Currently there are limited review on management of postharvest losses of fresh fruits and vegetables in Ethiopia due to lack of research works in the sector. Being able to maintain a level of freshness perishables horticultural commodity from harvesting to the ultimate utilization presents many challenges. Therefore, there is an urgent need by developing feasible technology to extend the shelf life of fruits and vegetables for securing food and nutrition of the society.
\end{abstract}

Keywords: Loss management, Quality, food security

DOI: $10.7176 / \mathrm{FSQM} / 100-04$

Publication date:August $31^{\text {st }} 2020$

\section{INTRODUCTION}

Horticulture production is an opportunity to increase food security, nutrition and income for small-holder famers in Ethiopia. In order to increase food security it is not enough to increase the productivity in agriculture but there is also a great need to lower the losses since post-harvest losses contribute to undernourishment and food insecurity in developing countries (Parfitt et al., 2010). Historically horticulture research has focused on how to increase the production and little emphasis has been made on how to minimize post-harvest losses (Kitonja et al., 2011).

Use of appropriate packaging materials, proper storage facilities, post-harvest technologies, transportation and modern food processing techniques can help to reduce perishable food losses, maintain the quality of products(appearance, texture, flavor and nutritive value) and protect food safety which result a great significance for food security, economic growth and welfare of the society (Kader, 2013). Generating efficient, low-cost and indigenous technology minimizes post-harvest loss of fruits and vegetables as the largest groups of people in Ethiopia who suffer from food and nutrition insecurity who have insufficient land and lack of resources to provide sufficient income generation through production of fruits and vegetables with integrated post-harvest technology (Mulatu, 2010).

After the time of harvest to the ultimate utilization, there is deterioration and death fruits and vegetables, everybody wants to ensure that the customers will enjoy this healthy harvest. The basic question in this review is how the quality and safety of the produce could be maintained during the time from harvest up to consumption. High quality and disease free produce with a good shelf life is the result of sound production practices providing food and nutrition security for the community. That is why we are initiating to review the possible ways to reduce post harvest losses of fruits and vegetables for securing food and nutrition.

\section{MANAGEMENT OF POST HARVEST LOSS}

Applying appropriate post harvest handling reduces post-harvest losses of horticultural crops (Atanda et al., 2011). Reducing food losses can increase food availability without requiring additional production resources and it can contribute to rural development and poverty reduction in less developed countries (Hodges et al., 2011). There are mitigation strategies of post harvest losses of fruits and vegetables such as using cultivars that have potential to last long after harvest, together with good flavor and high nutrition, maximizing yield without lowering quality and optimal handling of the product at all post-harvest stages (Kitinoja et al., 2011).

The sustainability of highly perishable horticultural products via post-harvest technology is important in ensuring food securities and enhancing the nutritional values of farm produce for a nation (Antunes et al., 2007). Post-harvest technology as the easiest, less costly and more efficient means of ensuring the perpetual supply of food to populations and a strategic pathway to reduce poverty, hidden hunger and malnutrition in African countries (Affognon et al., 2015).

\subsection{Harvesting}

Harvesting should be carried out as carefully as possible to minimize mechanical injury such as scratches, 
punctures and bruises to the crop. This should be carried out during the cool part of the day, which is early morning and late evening. Damage can be prevented by training harvest labor to handle the crop gently; harvesting at proper maturity; harvesting dry whenever possible; handling each fruit or vegetable no more than necessary (field pack if possible) (Hayatu, 2000; Atanda et al., 2011; Esguerra and Rolle., 2018). The method of harvesting can have a significant impact on the composition and postharvest quality of fruits and vegetables (Sudheer and Indira, 2007; Choi et al.,2017). Harvesting containers should be smooth, with no sharp edges or projections to damage the produce (Atanda, 2011).

\subsection{Handling}

All horticultural products should be handled gently to minimize mechanical injury such as bruising and breaking of the skin. Reducing the number of times the commodity is handled reduces the extent of mechanical damage. Fruits and vegetables crops should not be heaped at collection centre and not be exposed to the sun that will lead to rapid spoilage. Crops should be transferred promptly after harvest to a clean, cool, well-ventilated shed (Atanda, 2011).

\subsection{Minimal Processing}

Minimal processing refers to process steps such as cleaning, trimming, peeling, washing, slicing, dicing, sanitizing, shredding before packaging and many other operations depending on type and consumer requirements which is ready to use or ready to eat products to reduce loss and to increase marketability before final distribution (Patrignani et al., 2015). Minimally processed fruits and vegetable are prepared using non-thermal techniques to maintain freshness while keeping safety and quality right (Alegria et al., 2010; Gil et al., 2009).

\subsection{Temperature Management}

Temperature is an important factor that influences the postharvest life of fruits and vegetables (Alegria et al., 2010; Rudell et al., 2011).

\subsubsection{Low temperature Treatment}

Low temperatures treatment is one of the effective methods to preserve quality and extending postharvest life of fruits and vegetables (Aghdam et al., 2013). For effective temperature management removal of field heat is achieved by several pre cooling methods such as hydro cooling, ice toping, evaporative cooling, forced air cooling and vacuum cooling that precede further processing (Kitinoja, 2013; Yahaya, 2005).

\subsection{Heat treatment}

Blanching is pretreatment method used to inactivate deteriorating enzymes; maintain freshness color; stabilize texture and nutrients; controlling onset of fungal growth; killing of insects and microorganisms (Alegria et al., 2010; Mahajan et al., 2014; Xin et al., 2015). Blanching involves dipping of fruits or vegetables in boiling or near to boiling water for 1-3 min, depending on their size, shape and quantity of produce (Vaclavik \& Christian, 2014).

\subsection{1. Drying treatment}

According to Yahia (2004) dehydration alters the nature of the fruits and vegetables. However, drying can be used to extend the shelf-life of bulb crops, such as onions and garlic, while maintaining their fresh appearance by preventing water loss and microbial infection. This is done at a constant temperature of $30^{\circ} \mathrm{c}$ and $70 \% \mathrm{RH}$ over 7 to 10 days.

\subsection{2. Hot water treatment}

Produce may be dipped or using spray machine to control fungal growth, fungicides in conjunction with a hot water treatment can be highly effective. Heated solutions $\left(45^{\circ} \mathrm{C}\right)$ of sulphur dioxide, ethanol or sodium carbonate and imazalil at $25^{\circ} \mathrm{C}$ have been used to control green mould on citrus fruits. These treatments can accelerate the metabolic activity and can cause injury to the fruit if not used adequately (Yahia and Campos, 2000).

\subsubsection{Vapour Heat treatment}

Vapour heat treatment used to eliminate the insect pest without damaging the commodity (Yahia, 2004).

\subsubsection{Hot air treatment}

Hot air can be applied by placing fruit or vegetables in a heated chamber with a ventilating fan, or applying forced hot air with the circulation speed tightly controlled (Vaclavik \& Christian, 2014).

\subsection{5. Radio frequency treatment}

Radio frequency treatment could be used as part of an integrated approach, including proper packaging and adequate refrigeration, to improve the storability and food safety of horticultural produce (Orsat et al., 2001).

\subsubsection{Irradiation}

Ionizing irradiation (gamma rays, x-rays, electrons and microwaves) is used for the prevention of germination, sprouting, killing insects, retard ripening and aging which result prolong the shelf life of fruits and vegetables (Yahia, 2004). 


\subsection{Relative Humidity Management}

A few commodities of fresh produce should be kept at 90-95 \% RH to minimize water loss (Kitinoja and Kader, 2002). Managing relative humidity in horticultural commodity through adding moisture (water mist or spray, steam) to air by humidifiers; regulating air movement and ventilation in relation to the produce load in the cold storage room (Kader, 2013).

\subsection{Curing}

Curing is a simple and effective method to reduce water loss and decay during postharvest storage of root, tuber and bulb crops. Curing is self-healing of wounds, cute, abrasions, compressions and bruises with the development and suberization of new epidermal tissue (Atanda et al., 2011; Yahia, 2004).

\subsection{Dumping}

Dumping is the product moved from the field bin or harvesting container to the packinghouse. Dumping must be done gently, whether using water assisted methods or dry dumping. Wet dumping can decrease bruising and abrasions by using chlorinated (100-150 ppm) water to carry delicate produce (FAO, 1989).

\subsection{Cleaning and Sanitation/Good Personal Hygiene Practices}

Cleaning of harvested fruits and vegetables is very important as it assists in removing dirt and soil residue from them (Atanda et al., 2011) (Fig1a). Maintaining good personal hygiene practices is imperative for the avoidance of microbial and pathogenic infections that increase post-harvest losses of agricultural produce (Atanda, 2011; Sparks, 2013). Sanitizers such as chlorine, Iodine, Hydrogen Peroxide and other organic acids such as sodium hypochlorite solutions used to disinfect microbial and pathogenic infections (Arah et al., 2016). Sanitizing chemicals must be safe to the environment and human health, have trivial effect on produce quality and cost effective too (Joshi et al., 2013).

\subsection{Pre-sorting and Sorting}

Pre-sorting and sorting produce is usually done to eliminate injured, decayed or defective produce from the healthier and quality ones for storage, packaging and marketing purposes (Arah et al., 2016; Atanda, 2011; FAO, 1989).

\subsection{Grading}

Grading is an important component for good and effective marketing strategies. Fruits and vegetables are graded on the basis of shape, size, texture, colour, maturity, ripeness and general appearance (Arah et al., 2016). Fresh form of quality grades is critical for consumer marketing where as sizing produce is optional but may be worthwhile if certain size grades receive a higher price than others (FAO, 1989; Wakholi et al., 2015).

\subsection{Waxing/ Coating of the surface}

Fruits and vegetables contain a natural wax layer which deteriorates during postharvest handling treatments (such as washing, hot water treatments) substitute by artificial wax in order to prevent water loss, gas exchange, invasion of some micro-organisms and insects, reduce evaporation and respiration, minimize moisture losses; senescence and enzyme activity; preserve color, flavor and texture; protects against mechanical damage which retaining freshness and long shelf life of the produce (Atanda, 2011; Mahajan et al., 2014; Simson and Martha, 2010).

Approved fruit and vegetable edible coatings by Food and drug authority including chitosan, cellulose, starch, gum (polysaccharides), bees and paraffin wax (lipids), mineral oils, polyvinyl acetate and several proteins based (like gelatin and soy proteins) that proves good barrier properties without residue taste or odor impairment. They are mainly used in combination and incorporated with antioxidants, antimicrobials or nutraceuticals and functional compounds for improved shelf life, quality, stability, safety and nutrition of fruits and vegetables (Dhall, 2013).

\subsection{Packaging}

Use clean, smooth and ventilated containers for packaging (Fig1c). Packaging should be done adequately to offer protection to products from physical, mechanical, physiological and pathological deterioration during transportation, marketing and storage (Atanda, 2011; Esguerra and Rolle., 2018; Jat, 2010). Different fresh produces need different types of packages depending on their physical, anatomical and physiology (mainly transpiration, respiration and ethylene production rate) nature and susceptibility to microbial decay. Packaging types include containers, bags, sacks, baskets and a range of boxes. The packing material should be meeting the objective of packaging means that extend the shelf life of fruit and vegetable products which feets food security (Pankaj, k. 2010; Siddiqui, 2016; Yahaya, 2005;).

2.12.1. Special Chemical Treatment after packing

Post-harvest treatment of fruits and vegetables with poisonous chemicals should be avoided. The consumption of 
such fruits and vegetables should be delayed for at least one or two months as they may create health hazard most especially different respiratory and digestive disorders after consumption (Hayatu, 2000).

\subsubsection{Ethylene exclusion and removal}

Exposures of ethylene sensitive commodities to ethylene are cumulative and must be avoided throughout the postharvest handling system. The elimination of ethylene from the environment delays ripening and senescence of horticultural crops (Abeles, 1992; Bartz and Brecht, 2002).

Calcium Chloride $\left(\mathrm{CaCl}_{2}\right)$ is ethylene absorbent chemical used to suppress senescence, reduce chilling injury, control development of physiological disorders and increase disease resistance in stored fruits and vegetables at low temperature. Potassium permanganate an effective oxidizer of ethylene is commercially used as an ethylene scrubber (Abeles, 1992; El- Ramady et al., 2015; Pinzón-Gómez et al., 2014).

1-methylcyclopropene (1-MCP) is delivered as a gas and in aqueous solution on fruit and vegetable surfaces (Permana \& Broto, 2012; Pongprasert \& Srilaong, 2014). It is used to control ripening and senescence processes such as; pigment changes, de-greening, flavor and aroma development; cell wall metabolism, softening, scalding and browning without altering internal quality, nutrient contents and consumer acceptability of fruit and vegetables on a wide range of fruits and vegetables (Li et al., 2016; Minas et al., 2013; Watkins, 2014).

Ameno ethoxy vinyl gycine (AVG) and silver thio-sulfate (STS) which inhibit ethylene production and action during ripening and storage of fruits and vegetables, thereby extending shelf life (El-Ramady et al., 2015; Mahajan et al., 2014).

\subsubsection{Post-harvest plant hormones}

Gibberellic acid markedly delayed the ripening of banana and tomato (Elias et al., 2010; Hayatu , 2000). Application of Malic hydrazide (MH) on onion and potato before harvest which inhibits sprouting in storage that extends the shelf life of products and reduced the loss, and it is very effective to delays the ripening of mangoes. Application of Indole Acetic Acid (1AA) solution helps to maintain the green colour of pods of many vegetables (FAO, 2011)

\subsubsection{Fungicides}

Fungicides commonly applied as dips or sprays include the benzimidazoles (e.g. benomyl and thiabendazole) and the triazoles (e.g. prochloraz and imazalil). The benzimidazole groups of fungicides are very useful for the control of many important postharvest pathogens such as Penicillium and Colletotrichum. Fumigants such as sulphur dioxide, carbon dioxide, ozone and ammonia, bi-phenyl acetaldehyde, propylene oxide, ethylene oxide; nitrogen trichloride, methyl bromide or phosphine inhibit the activity of a number of pests (microorganisms and insects) and extend the shelf life and added nutritive value to foods (Elias et al., 2010).

\subsection{Storage}

Storage is keeping the quality of agricultural materials and preventing them from deterioration for specific period of time, beyond their normal shelf life (Kiaya, 2014). Storage is important to extend the shelf life of fruits and vegetables and increases their period of food availability and reduces malnutrition by controlling the rate of respiration, transpiration, ripening and undesirable biochemical changes and disease infection (Arah et al., 2016; Khan et al., 2017).

\subsubsection{Zero energy cool chambers (ZECC)}

Zero energy cool chambers are systems used for storage based on the principles of direct evaporative cooling. It is on-farm low cost cooling technology and materials used to construct this storage are easily available such as bricks, sand, bamboo etc (fig 1b). Electric power is not important to operate (Khan et al., 2017).

\subsubsection{Cold Storage}

The most suitable condition for fresh fruits and vegetables in storage is the lowest temperature, which does not cause chilling injury to the fresh produce. Fruits and vegetables can be safely kept for a long period through refrigeration (Danladi, 2000).

\subsubsection{Controlled atmosphere storage}

Controlled Atmosphere Storage (CAS) is controlling the gaseous atmosphere in a store has been shown to improve the maintenance of their postharvest quality over controlling the temperature and humidity (Thompson, 1998).

\subsubsection{Modified atmospheric storage (MAS)}

Modified atmosphere refers to the use of atmospheres with different gas composition than that of the normal air, which has about $21 \% \mathrm{O}_{2}, 78 \% \mathrm{~N}_{2}, 0.03 \% \mathrm{CO}_{2}$, and traces of other gases. Apply lowering the $\mathrm{O}_{2}$ (below $1 \%$ ) or raising the $\mathrm{CO}_{2}$ concentration above $5 \%$ can suppress pathogenic growth on the fruit and vegetables which increase food security (Shen and Huang, 2003).

\subsection{Transportation}

Produce should be kept at optimum conditions during the transport. The load must be stacked effectively such that air is well circulated and respiration heat from the produce is removed (Kitinoja and Kader, 2002; Sparks, 2013). Transport crops during the cool part of the day by driving carefully over smooth roads to minimize damage to crop. 
Speedy transport of fruits and vegetable is very important for successful marketing and maintenance of good quality since short transit period which minimize losses (Dudi, 2014; SATNET; 2014).

\subsection{Processing}

Fruits and vegetables can be preserved for relatively long period by drying, freezing and canning (Barber and Husting, 1977). Sun drying is the simplest and lowest cost method of preservation and should be more widely used in developing countries because it converts a perishable commodity into a stable item with long storage life (Atanda, 2011)

\subsection{Role of mass media}

Post-harvest information disseminated through the mass media as a strategy to minimize post harvest losses of fruits and vegetables. Advertisements and promotion programmes on post-harvest practices of food items should be carried-out to motivate proper attitudes towards reducing food losses (Kader, 2013).

\subsection{Participation of policy makers}

Participation of policy makers in the development of postharvest industry is essential. Providing policy guidelines for increasing post-harvest research and development activities carried out by research institutions and universities to determine the best suited technology to the farmers used for securing food and nutrition (Kader, 2013).

\subsection{Marketing}

A perfect and efficient marketing system is essential to avoid the losses of fruits and vegetables, and it is possible when the market needs the produce most and also to get a good return for the effort and money spend (Yahaya et al., 2015).

\subsection{Consumer's behavior}

The extent of post-harvest losses at the consumer level can be related to their educational level, income, taste, preference, attitude and family size. It is expected that the higher the educational attainment of the consumer, lesser will be the food losses or vice-versa. The consumers have stronger preference for freshly harvested fruits and vegetables than stored ones. The tendency of some consumers to over purchase cheap but highly perishable fruits and vegetables has led to wastage due to inadequate storage facilities (Pankaj,K. 2010).

\section{CONCLUSION}

Postharvest management is a set of post production practices that includes using appropriate harvesting practices and methods, cleaning, washing, sorting, grading, disinfection, proper packaging, proper storage facilities, adequate transportation, efficient marketing, modern food processing techniques and best utilization. These maintain the quality of products and protect food safety which ensures a great significance for food security, economic growth and welfare of the society. Currently there are limited review on management of postharvest losses of fresh fruits and vegetables in Ethiopia due to lack of research works in the sector. Being able to maintain a level of freshness perishables horticultural commodity from harvesting to the ultimate utilization presents many challenges. Therefore, there is an urgent need by developing feasible technology to extend the shelf life of fruits and vegetables for securing food and nutrition of the society.

\section{REFERENCES}

Abeles, F.B., Morgan, P.W., Saltveit ME (1992). Ethylene in Plant Biology, vol. 15, 2nd ed. Academic Press, San Diego, California.

Affognon, H., Mutungi, C., Sanginga, P., \& Borgemeister, C. (2015). Unpacking postharvest losses in sub-Saharan Africa: A meta-analysis. World Development, 66, 49-68. http://dx.doi.org/10.1016/j.worlddev.2014.08.002

Aghdam, M. S., Sevillano, L., Flores, F. B., \& Bodbodak, S. (2013). Heat shock proteins as biochemical markers for postharvest chilling stress in fruits and vegetables. Scientia Horticulturae, 160, 54-64. http://dx.doi.org/10.1016/j.scienta.2013.05.020

Alegria, C., Pinheiro, J., Gonçalves, E. M., Fernandes, I., Moldao, M., \& Abreu, M. (2010). Evaluation of a precut heat treatment as an alternative to chlorine in minimally processed shredded carrot. Innovative Food Science \& Emerging Technologies, 11, 155-161. http://dx.doi.org/10.1016/j.ifset.2009.10.008

Antunes, D., Miguel, G. \& Neves, A. (2007). Sustainable Post-harvest Handling of Horticultural Products. WSEAS Transactions on Environment and Development, vol. 3, Issue 6

Arah, I. K., Ahorbo, G. K., Anku, E. K., Kumah, E. K. \& Amaglo, H. (2016). Postharvest Handling Practices and Treatment Methods for Tomato Handlers in Developing Countries: A Mini Review. Advances in Agriculture, vol. 2016, pp. 1- 8, Hindawi Publishing Corporation.

Atanda, S. A., Pessu, P. O., Agoda, S., Isong, I. U. \& Ikotun, I. (2011). The Concepts and Problems of Post-Harvest 
Food Losses in Perishable Crops. African Journal of Food Science, vol. 5(11), pp. 603-613.

Bartz, J.A. and Brecht, J.K. (2002). Postharvest physiology and pathology of vegetables, $2^{\text {nd }}$ ed. Marcel Dekker, New York.

Choi YS, Han BH, Yoo SN. 2017. Harvesting performance of an experimental pick-up type pulse crop

harvester for green kernel black bean. Korean Journal of Agricultural Science 44:114-122.

Postharvest technologies for fruits and vegetables in South Asian countries: a review

Danladi DK (2000) Nigeria agriculture: The efficiency factor announce this article to your friends. p.1-3.

Dhall, R. (2013). Advances in edible coatings for fresh fruits and vegetables: A review. Critical Reviews in Food Science and Nutrition, 53, 435-450. http://dx.doi.org/10.1080/10408398.2010.541568

Dudi, J. A. (2014). Assessment of Post-harvest Grain Management Operations and their Effects on Food Security of Smallholder Households in Kisumu County, Kenya. M. A. Thesis, Kenya: University of Nairobi.

Elias SN K, Shaw MW, Dewey FM (2010) Persistent symptomless, systemic and seed-borne infection of lettuce by Botrytis cinerea. European Journal of Plant Pathology 126(1): 61-71.

El-Ramady, H. R., Domokos-Szabolcsy, É., Abdalla, N. A., Taha, H. S., \& Fári, M. (2015). Postharvest management of fruits and vegetables storage sustainable agriculture reviews (pp. 65-152). New York, NY: Springer.

Esguerra, E.B. \& Rolle, R. (2018).Post-harvest Management of Mango for Quality and Safety Assurance. Guidance for Horticultural Supply Chain Stakeholders. Rome: Food and Agriculture Organization of the United Nations.

FAO, 1989. Prevention ofpost-harvest food losses: fruits, vegetables, and root crops. A training manual. Availableat:http://www.fao.org/docrep/T0073E/T0073E03.htm\#5.\%20Harvesting\%20and\%20field\%20han dling.

FAO (Food and Agriculture Organization). 2011. Maldives and FAO achievements and success stories.pp. 1-12. FAO, Rome, Italy.

Gil, M. I., Selma, M. V., López-Gálvez, F., \& Allende, A. (2009). Fresh-cut product sanitation and wash water disinfection: Problems and solutions. International Journal of Food Microbiology, 134, 37-45. http://dx.doi.org/10.1016/j.ijfoodmicro.2009.05.021.

Hayatu M (2000) Post-Harvest physiological studies of some selected members of family Solanaceae. Kano, p. 2 25.

Hodges, R. J., Bennet, B.and Buzby, J,C. (2011). Postharvest losses and waste in developed and less developed countries: Opportunities to improve resource use. Natural Resources Institute, University of Greenwich, Chatham Maritime, Kent . The Journal of Agricultural Science 149(S1):37 - $45 \cdot$ February 2011.

Jat SR. 2010. Technology on reducing post-harvest losses and maintaining quality of fruits and vegetables. pp. 114-124. 2010 AARDO Workshop on Technology on Reducing Post-Harvest Losses and Maintaining Quality of Fruits and Vegetables. Department of Horticulture, Government of Rajasthan, India.

Joshi, K., Mahendran, R., Alagusundaram, K., Norton, T., \& Tiwari, B. (2013). Novel disinfectants for fresh produce. Trends in Food Science \& Technology, 34, 54-61. http://dx.doi.org/10.1016/j.tifs.2013.08.008

Kader, A. A. 2004. Increasing food Availability by reducing postharvest losses of fresh produce. The V International Postharvest Symposium 682 (pp. 2169-2176).

Kader, A. (2013). Postharvest technology of horticultural crops- An overwiew from farm to fork. Ethiopian Journal of Science and Technology, 1, 1-8

Khan F., Bhat S., Narayan S. (2017). Storage Methods for Fruits and Vegetables.

Kiaya, V. (2014). Post-harvest losses and strategies to reduce them. Technical Paper on Postharvest Losses, Action Contre la Faim $(A C F)$.

Kitinoja, L. (2010). Identification of appropriate postharvest technologies for improving market access and incomes for small horticultural farmers in Sub-Saharan Africa and South Asia. WFLO Grant Final Report. Grant number 52198.

Kitinoja, L. (2013). Innovative small-scale postharvest technologies for reducing losses in horticultural crops. Ethiopian Journal of Applied Science and Technology, 1, 9-15.

Kitinoja, L., Saran, S., Roy, S. K., \& Kader, A. A. (2011). Postharvest technology for developing countries: challenges and opportunities in research, outreach and advocacy. Journal of the Science of Food and Agriculture, 91, 597-603. http://dx.doi.org/10.1002/jsfa.4295

Kitinoja, L. \& Kader, A. A. (2002). Small-Scale Post-harvest Handling Practices: A Manual for Horticultural Crops (4th Ed.). Davis: University of California

Li, L., Lichter, A., Chalupowicz, D., Gamrasni, D., Goldberg, T., Nerya, O., ... Porat, R. (2016). Effects of the ethylene action inhibitor 1-methylcyclopropene on postharvest quality of non-climacteric fruit crops. Postharvest Biology and Technology, 111, 322-329.

Mahajan, P. V., Caleb, O. J., Singh, Z., Watkins, C. B., \& Geyer, M. (2014). Postharvest treatments of fresh produce. Philosophical Transactions of the Royal Society Publication A: Mathematical, Physical and 
Engineering Sciences, 327:1-19.. http://dx.doi.org/10.1098/rsta.2013.0309

Minas, I. S., Crisosto, G. M., Holcroft, D., Vasilakakis, M., \& Crisosto, C. H. (2013). Postharvest handling of plums (Prunus salicina Lindl.) at $10^{\circ} \mathrm{C}$ to save energy and preserve fruit quality using an innovative application system of 1-MCP. Postharvest Biology and Technology, 76, 1-9. http://dx.doi.org/10.1016/j.postharvbio.2012.08.013

Mulatu W., 2010. Solar drying of fruits and windows of opportunities in Ethiopia. Afr J Food Sci;4(13):790-802.

Mustapha, Y. and Yahaya, S.M. (2006). Isolation and Identification of Post-harvest fungi of Tomato ( $L$. esculentum) and Pepper (Capsicum annum) sample from selected Irrigated sites in Kano. Biological and Environmental Science Journal for the Tropics 3: 139-141.

Orsat V, Change V, Raghavan GV. 2015. Microwave drying of fruits and vegetables. Stewart Postharvest Technology 6:1-7.

Pankaj, K. (2010). The Central Institute of Post-Harvest Engineering and Technology. Horticultural Crop Processing. Ludhiāna, India

Parfitt, J., Bathel, M. \& Macnaugton, S. (2010). Food waste within food supply chains: quantification and potential for change to 2050. The Royal Society, 365, 3065-3081.

Patrignani, F., Siroli, L., Serrazanetti, D. I., Gardini, F., \& Lanciotti, R. (2015). Innovative strategies based on the use of essential oils and their components to improve safety, shelf-life and quality of minimally processed fruits and vegetables. Trends in Food Science \& Technology, 46, 311- 319. http://dx.doi.org/10.1016/j.tifs.2015.03.009.

Permana, A., \& Broto, W. (2012). Characterization of 1-mcp gas from synthesis of various ratios of lithium diisopropylamide (LDA) and 3-chloro-2-methylpropene (CMP). Paper presented at the II Asia Pacific Symposium on Postharvest Research Education and Extension: APS2012 1011, Yogyakarta.

Pinzón-Gómez, L. P., Deaquiz, Y. A., \& Álvarez-Herrera, J. G. (2014). Postharvest behavior of tamarillo (Solanum betaceum $\mathrm{Cav}$.) treated with $\mathrm{CaCl} 2$ under different storage temperatures. Agronomía Colombiana, 32, 238245. http://dx.doi.org/10.15446/agron.colomb.v32n2.42764

Pongprasert, N., \& Srilaong, V. (2014). A novel technique using 1-MCP microbubbles for delaying postharvest ripening of banana fruit. Postharvest Biology and Technology, 95, 42-45. http://dx.doi.org/10.1016/j.postharvbio.2014.04.003.

Rudell, D. R., Buchanan, D. A., Leisso, R. S., Whitaker, B. D., Mattheis, J. P., Zhu, Y., \& Varanasi, V. (2011). Ripening, storage temperature, ethylene action, and oxidative stress alter apple peel phytosterol metabolism. Phytochemistry, 72, 1328-1340.http://dx.doi.org/10.1016/j.phytochem.2011.04.018

SATNET (2014). Post-harvest Technology and Marketing Systems for Small-Scale Farmers. 10-14 March, 2014, Royal University of Agriculture, Cambodia, Training Report. AGRA

Siddiqui, M.W. (2016). Eco-friendly technology for postharvest produce quality: Academic Press.

Simson,S.P. and Martha,C,S.(2010). Post-Harvest Technology of Horticultural Crops. Oxford Book Company, PP $2010-315$.

Shen, L.Q., and Huang, G.R. 2003. Study on modified atmosphere packaging of Myricarubra. Journal of Zhejiang University of Science and Technology, 15:232-235.

Sparks, S. A. (2013). Post-harvest Handling Systems for Fresh Fruits and Vegetables in Sub-Saharan Africa and Potential Enhancement by the Aid for Trade Initiative. Master of Science Thesis, Athens: University of Georgia

Sudheer K, Indira PV. 2007. Post-parvest technology of horticultural crops. pp. 17-64. New India

Publishing Agency, New Delhi, India.

Swinnen JF. 2007. Global supply chains, standards and the poor: How the globalization of food systems

and standards affects rural development and poverty. pp. 91-108. CABI, Trowbridge, UK.

Thompson, A.K. (1998). Controlled atmosphere storage of fruits and vegetables. CAB International, London.

Vaclavik, V. A., \& Christian, E. W. (2014). Food preservation essentials of food science (pp. 323-342). New York, NY: Springer. http://dx.doi.org/10.1007/978-1-4614-9138-5

Wakholi C, Cho BK, Mo C, Kim MS. 2015. Current state of postharvest fruit and vegetable management in east africa. Journal of Biosystems Engineering 40:238-249.

Watkins, C. B., \& Nock, J. F. (2012). Production guide for storage of organic fruits and vegetables.

Xin, Y., Zhang, M., Xu, B., Adhikari, B., \& Sun, J. (2015). Research trends in selected blanching pretreatments and quick freezing technologies as applied in fruits and vegetables: A review. International Journal of Refrigeration, 57, 11-25. http://dx.doi.org/10.1016/j.ijrefrig.2015.04.015

Yahaya SM (2005) Contribution of harvest to pathogenic and non-pathogenic losses of vegetables grown in Kano State- Nigeria. Bayero University, Kano.

Yahaya SM, Fagwalawa LD, Ali MU, Lawan M, Mahmud S (2015) Isolation and Identification of Pathogenic Fungi Causing Deterioration of Lettuce Plant (Lactuca sativa) A Case Study of Yankaba and Sharada Vegetables Markets. J Plant Sci Res 3(1): 1-4. 
Yahia, E.M. (2004). Date. In: Gross K, Wang CY Saltveit M, editors. The Commercial Storage of Fruits, Vegetables and Florist and Nursery Crops. Agriculture Handbook 66. Beltsville, MD: USDA. 3p.

Figure1. Different management activities in Ethiopia (Photo assisted by Sintayehu M.2018)

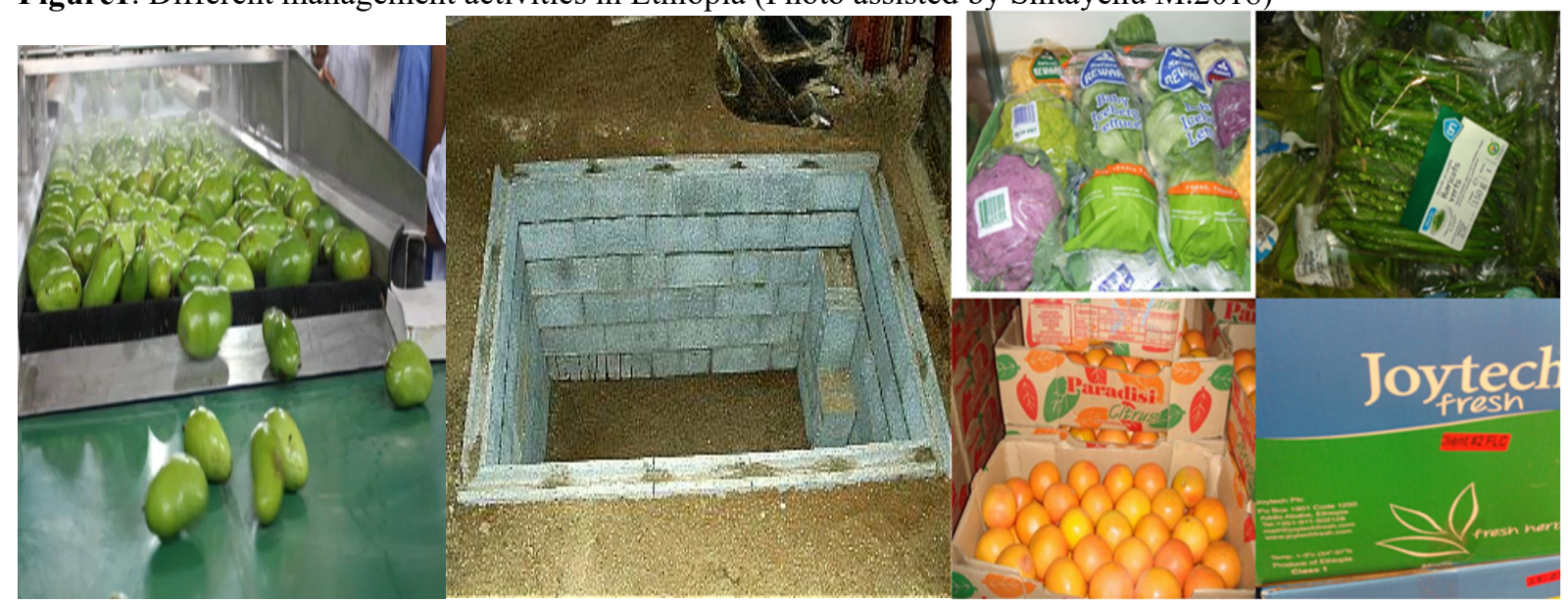

A) Cleaning/Sanitation

B) Zero energy cooling chamber

C) Packaging 